\title{
Antimicrobial Activities of Propolis against Oral Candidiasis by Candida Albicans -Effect of Microbial Inhibition Using Propolis-
}

\author{
Hyeon-Sook Kwun', Seoul-Hee Nam', Min-Kyoung Park ${ }^{2}$ \\ Mi SooK Cho ${ }^{3}$, Sae-Hee Cheon ${ }^{1 *}$ \\ Depart. of Dental Hygiene, Masan University \\ ${ }^{2}$ Depart. of Dental Hygiene, Kyung-woon University \\ Depart. of Dental Hygiene, Coonhae Colleage of Health Sciences

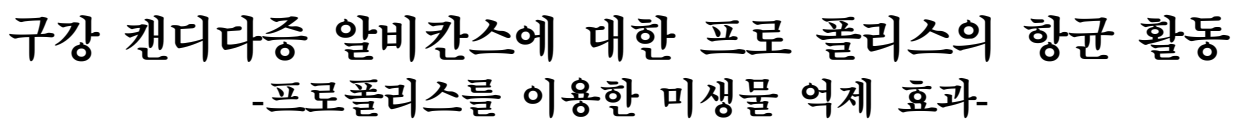 \\ 권현숙 ${ }^{1}$, 남설희 ${ }^{1}$, 박민경 ${ }^{2}$, 조미숙 ${ }^{3}$, 천세희 ${ }^{*}$ \\ '마산대학교 치위생과, ${ }^{2}$ 경운대학교 보건대학 치위생학과, ${ }^{3}$ 춘해보건대학 치위생과
}

\begin{abstract}
Propolis is an extremely safe natural antimicrobial substance that has been reported to have powerful antibacterial efficacy. The aim of this study was to evaluate the inhibitory effects of propolis against Candida albicans (C. albicans). Propolis was collected from the honey bee Apis mellifera. The strain of C. albicans was cultivated overnight in liquid media incubated at $37^{\circ} \mathrm{C}$. The antimicrobial activity was investigated using phosphate buffered saline (PBS), 3\% sodium hypochlorite $(\mathrm{NaOCl}), 0.1 \%$ chorhexidine $(\mathrm{CHX})$, and propolis extracts $(5 \mu \mathrm{l} / \mathrm{ml}, 10 \mu \mathrm{l} /$ $\mathrm{ml})$. C. albicans were sensitive to $3 \% \mathrm{NaOCl}, 0.1 \% \mathrm{CHX}$, and propolis $(5 \mu \mathrm{l} / \mathrm{ml}, 10 \mu \mathrm{l} / \mathrm{ml})$ with zones of inhibition of $15,14.5,16$, and $17 \mathrm{~mm}$, respectively. The CFU of PBS, $3 \% \mathrm{NaOCl}, 0.1 \% \mathrm{CHX}, 5 \mu \mathrm{l} / \mathrm{ml}$ and $10 \mu \mathrm{ll} / \mathrm{ml}$ of propolis led a 1, 7, 7, 5 and 7-log reduction. Among the groups tested, C. albicans was most sensitive to $10 \mu \mathrm{l} / \mathrm{ml}$ of propolis, which showed the largest inhibition zones. Therefore, propolis can be a new antimicrobial therapy for oral mucosa disease in traditional medicine.

요 약 본 연구는 칸디다 알비칸스(C. albicans)에 대한 프로폴리스의 억제효과를 확인하고자 수행되었다. 프로폴리스는 양봉 꿀벌에서 채취하여 C. albicans는 $37^{\circ} \mathrm{C}$ 에서 액체 배지에서 2 시간 배양 하였다. 항균 활성검삼를 위해서 생리식염수 (PBS), $3 \%$ 차아염소산나트륨 $(\mathrm{NaOCl}$ 에), $0.1 \%$ 클로로헥시딘 $(\mathrm{CHX})$, 프로 폴리스 추출물 $(5 \mu \mathrm{L} / \mathrm{ml}, 10 \mu \mathrm{L} / \mathrm{m} \ell)$ 에서 평가하 였다. C. albicans는 $3 \%$ 의 NaOCl, $0.1 \% \mathrm{CHX}$, 프로 폴리스 $(5 \mu \mathrm{L} / \mathrm{m} \ell, 10 \mu \ell / \mathrm{m} \ell)$ 에서 $15,14.5,16,17 \mathrm{~mm}$ 의 억제구간을 확인하 였다. 항균활성을 확인하기 위하여 집락형성을 분석한 결과, $3 \%$ 의 NaOCl, $0.1 \% \mathrm{CHX}, 5 \mu \mathrm{L} / \mathrm{ml}$ 와 $10 \mu \mathrm{L} / \mathrm{ml}$ 의 프로 폴리스 가 7, 7, 5,7 로그지수가 감소를 보였다. C. albicans서는 $10 \mu \mathrm{L} / \mathrm{m} \ell$ 의 프로폴리스에서 유의하게 억제되는 결과를 보여주었다. 이러한 결과를 통하여 프로폴리스는 구강 점막 질환에서 새로운 향균 약제가 될수 있는 것으로 생각된다.
\end{abstract}

Key Words : antimicrobial effect, C. albicans, oral mucosa disease, propolis

\section{Introduction}

Propolis is known as bee glue and is resinous substance that honey bees extract from flower buds and plant. It is used to reinforce the structural stability in the bee hive[1]. The name comes from the Greek

\footnotetext{
"Corresponding Author : Sae-Hee Cheon(Masan Univ.)

Tel: +82-10-3587-3004 email: bobo9576@naver.com

Received June 13, $2014 \quad$ Revised August 12, $2014 \quad$ Accepted September 11, 2014
} 
'pro', in front, and 'polis' meaning town or city, and bees use propolis to seal their hives against invasion by other insects and the weather[2].

Propolis contains several types of flavonoids, including antibacterial, antifungal, antiprotozoan, antiviral, antitumor, immunomodulation and anti-inflammatory activities as well. Numerous studies also proven its resourceful pharmacological activities: antibacterial, antifungal, antiviral, anti-inflammatory, antitumor, as well as immunomodulatory action, radio-protective, and so forth[3-10]. The chemical composition of propolis is very complex and includes organic compounds such as phenolic compounds and esters, flavonoids in all their forms(flavonols, flavones, flavonones, dihydroflavonols, and chalcones), terpenes, beta-steroids, aromatic aldehydes and alcohols, sesquiterpenes, and stilbene terpenes[11].

Among these functional properties, the propolis contains a large amount of flavonoids in mineral substance and in the various organisms' substance. These flavonoids have been reported as a powerful antibacterial efficacy[12]. Flavonoids in propolsis are well known to be protective of the occurrence of lipid peroxidant not only the hydrolysis but also inhibitors[13]. It is an alternative medicine not chemical agent and it's possible in supporting conventional process of healing as natural products[14]. Therefore, if ingested, propolis is extremely safe natural antimicrobial substance without any toxic[15]. Despite increasing use of propolis worldwide[16] only a few studies have been carried out to determine the inhibitory effect of propolis against some bacteria and fungi of relevance in dentistry[17].

Recently, Propolis components have been used for the purpose of the oral prevention for dental caries, halitosis, periodontal diseases.

Therefore, natural substance such as green tea components, chitosan, and aloe are used to attempt to add the composition in the mouthwashes products[18,19].

The activities of propolis suggest its possible use in the local treatment of infectious conditions. Maryam et al. reported that propolis is one of disinfective agents for root canal treatment and it is also a new alternative substance as an intracanal medicaments. In their study, it showed that minimum inhibitory concentrations and colony forming units of propolis were significantly less than calcium hydroxide[20].

Oral mucosa disease is one of the most common infectious by a variety of infections in the bacteria, virus, systemic disease, nutritional disorder, and stress[21]. Oral candidiasis is an opportunistic fungus as a form of yeast, which is generally present on the skin and in mucous membranes like a rectum, mouth, and throat. The Candida albicans (C. albicans) fungus also can pass through the blood vessels and affect intestines, throat, and heart valves. The most typical species is C. albicans, which is a major cause of oral candidiasis or yeast infection in the oral mucosa[22]. Treatment of antibiotics, steroids, and antifungal agents can weaken the immune system and decline in the normal bacteria flora, leading to superinfection[23].

By these reasons, propolis can use the bio-medical applications for antimicrobial effect. Therefore, the aim of this study was to evaluate the antimicrobial effect of propolis against $C$. albicans.

\section{Materials and methods}

\subsection{Propolis preparation}

Propolis was collected from the honey bee Apis mellifera in Geochang County, Gyeongsan gnam-do, Southeast Korea.

\subsection{Bacterial strains and culture conditions}

The strain of C. albicans(KCTC 7965/ATCC 10231) was used as the test organism. The strain of $C$. albicans was grown in yeast mold broth(Difco, USA) and cultivated over night in liquid media incubated at $37^{\circ} \mathrm{C}$. The cell was diluted in phosphate buffered saline(PBS) to a final concentration approximately 
$5 \times 10^{6}$ colony-formingunits(CFU)permilliliter.

\subsection{Antimicrobial effects}

Antimicrobial activity was investigated using ager diffusion method. Sterilized filter paper disc(Advantec Toyo Kaisha, Ltd) of $8 \mathrm{~mm}$ diameter were impregnated with $100 \mu \mathrm{l}$ of PBS, 3\% Sodium hypochlorite( $\mathrm{NaOCl}$ ), 0.1\% Chorhexidine(CHX), and propolis extracts $(5 \mu \mathrm{l} /$ $\mathrm{ml}, 10 \mu \mathrm{l} / \mathrm{ml})$. There were control tubes with the liquid medium(without propolis) as negative controls and PBS $3 \% \mathrm{NaOCl}$, and $0.1 \% \mathrm{CHX}$ as positive controls. The inhibitory zone was considered the distance $(\mathrm{mm})$ from the outside margin of the samples to the initial point of the microbial growth. Each liquid medium was cultured into tubes and these cultures were incubated at $37^{\circ} \mathrm{C}$ for $24 \mathrm{~h}$, and a single test tube was used for evaluating CFU. The inhibition assays were performed in sterile 96-well plates, and the optical density(OD) was detected using micro plate reader(BioTek Instruments, Winooski, VT, USA) at the wavelength of $550 \mathrm{~nm}$. All tests were performed in triplicate.

\subsection{Statistical analysis}

Statistical analysis was performed using SPSS(IBM Co., Armonk, NY, USA). The clean zone and logarithms of each C. albicans plate count were taken and analysis using one-way analysis of variance(ANOVA) to check the difference in bacterial inhibition among the groups. $\mathrm{P}$ value of $<0.05$ was considered statistically significant.

\section{Results and Discussion}

Oral C. albicans have been found as normal flora in 30-45\% of healthy adults[24]. An opportunistic infection is any infection caused by pathogen that doesn't normally lead to disease in healthy humans. When immune system is reduced, the number of $C$. albicans rapidly increased to induce the oral candidiasis[25]. Particularly, it usually occurs in children, the elderly and people with impared immunity[26] and the people who are poor oral hygiene, have systemic disease, and cancer patients undergoing chemotherapy[27].

\subsection{Antibacterial activity of C. albicans}

The susceptibility of $C$. albicans to YM broth, PBS, $3 \% \mathrm{NaOCl}, 0.1 \% \mathrm{CHX}$, and propolis $(5 \mu \mathrm{l} / \mathrm{ml}, 10 \mu \mathrm{l} / \mathrm{ml})$ was evaluated in solid and liquid culture. In a disc diffusion assay, $C$. albicans were sensitive to 3\% $\mathrm{NaOCl}, 0.1 \% \mathrm{CHX}$, and propolis $(5 \mu \mathrm{l} / \mathrm{ml}, 10 \mu \mathrm{l} / \mathrm{ml})$ with zones of inhibition of 15, 14. 5, 16 and $17 \mathrm{~mm}$, respectively. Table 1 provides the mean values of inhibition zones diameter obtained for each tested groups by diffusion method.

[Table1] Antibacterial activity by disc diffusion method.

\begin{tabular}{|c|c|c|c|}
\hline $\begin{array}{l}\text { Application } \\
\text { name }\end{array}$ & $\begin{array}{c}\text { Concentration } \\
(\mu 1 / \text { disk })\end{array}$ & Clear zone & Activity \\
\hline $\begin{array}{c}\text { Control } \\
\text { (No-treat.) }\end{array}$ & 100 & No & - \\
\hline PBS & 100 & No & - \\
\hline $3 \% \mathrm{NaOCl}$ & 100 & $\begin{array}{c}15.0 \pm 0.75 \\
\mathrm{~mm}\end{array}$ & +++ \\
\hline $0.1 \% \quad \mathrm{CHX}$ & 100 & $\begin{array}{c}14.5 \pm 0.25 \\
\mathrm{~mm}\end{array}$ & +++ \\
\hline $\begin{array}{l}5 \mathrm{ul} / \mathrm{ml} \\
\text { Propolis }\end{array}$ & 100 & $\begin{array}{c}16.0 \pm 0.40 \\
\mathrm{~mm}\end{array}$ & ++++ \\
\hline $\begin{array}{l}10 \mu \mathrm{l} / \mathrm{ml} \\
\text { Propolis }\end{array}$ & 100 & $\begin{array}{c}17.0 \pm 0.65 \\
\mathrm{~mm}\end{array}$ & ++++ \\
\hline
\end{tabular}

As the concentration of the propolis loaded on the disc increased, the clean zone around the paper disc also increased. Among the tested groups, the most sensitive to $C$. albicans was $10 \mu \mathrm{l} / \mathrm{ml}$ of propolis, which showed the highest inhibition zones[Fig. 1]. 


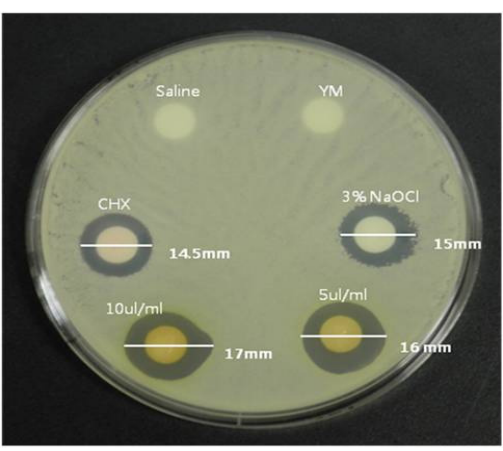

[Fig. 1] 4. Clear zone of C. albicans

The number of counted colonies after 24h incubation is demonstrated in Fig. 2(A). The CFU of PBS, 3\% $\mathrm{NaOCl}, 0.1 \% \mathrm{CHX}, 5 \mu \mathrm{l} / \mathrm{ml}$ and $10 \mu \mathrm{l} / \mathrm{ml}$ of propolis led $1,7,7,5$ and $7-\log$ reduction of $C$. albicans, respectively [Fig. 2(B)].

(A)

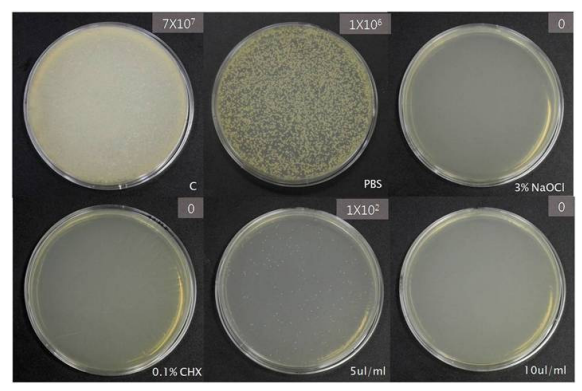

(B)

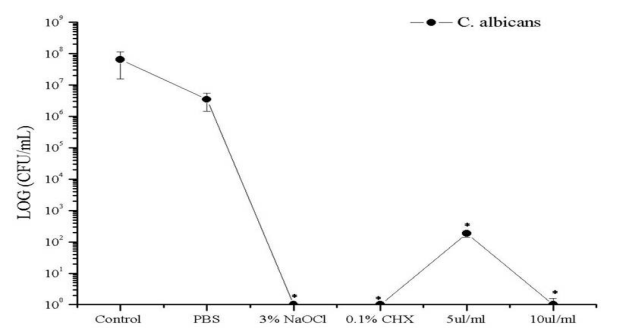

[Fig. 2] Anti-bacterial effect of C. albicans. (A) The viability was typically assessed by plate counting and (B) bactericidal activity by $\mathrm{CFU}\left({ }^{*} \mathrm{p}<0.01\right)$.

Fig. 3 shows the OD measurement at each tested groups. In a broth culture, the cell number of was significantly reduced in $3 \% \mathrm{NaOCl}, 0.1 \% \mathrm{CHX}$ and 10 $\mu \mathrm{l} / \mathrm{ml}$ of propolis. The $10 \mu \mathrm{l} / \mathrm{ml}$ concentration of propolis was showed anti-microbial effects, which succeeded in inhibiting the growth of the microorganisms.

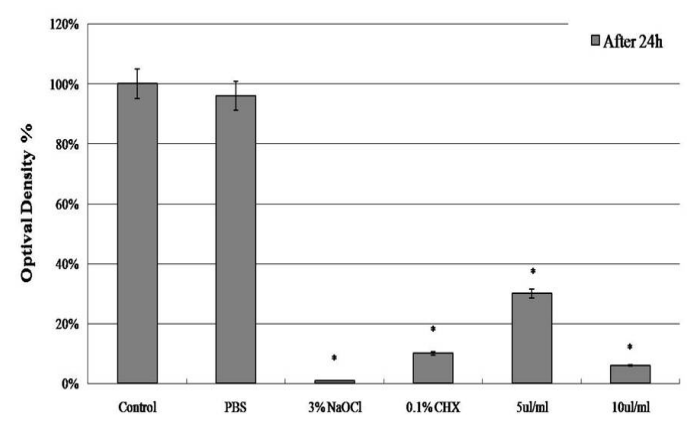

[Fig. 3] The killing effects of the cell viability against C. $\operatorname{albicans}\left({ }^{*} \mathrm{p}<0.01\right)$

The disinfectants such as $\mathrm{NaOCl}$ and $\mathrm{CHX}$ had good antibacterial activity. Both disinfectants significantly reduced the cultivable number of bacteria. $\mathrm{NaOCl}$ is an effective antimicrobial agent[28] and an excellent organic tissue solvent[29], but has a highly toxic effect on the periapical tissues[30]. CHX is a broad-spectrum antimicrobial agent[31] that has substantive antibacterial activity and relatively low toxic effects[32]. However, it does not dissolve organic tissue[33]. In addition, the systemic administration of antimicrobials has been reported to cause the development of multiresistant microorganisms, interbacterial transfer of resistance determinants, and side effects[34].

The exploration for improved therapeutic efficacy will open newer agents in drug delivery[35]. Due to resistance to antibiotics by pathogens, recent research has been directed towards the use of traditional medicine/natural products for treatment and control of infections. The application of natural agents can inhibit bacterial colonization, growth, and metabolism[36]. Propolis is one of such products that is being tested on pathogens. There are a number of studies documenting the biocidal functions of propolis, its extracts and constituents. The propolis antibacterial activity is very 
significant, since many of the assayed bacteria present resistance against antibiotics in clinical use[37]. Ghisalberti[38] found that propolis possesses several medicinal properties, i.e. antibacterial, anti-ulcer and fungicidal properties. Park et al.[39] showed the presence of the inhibitory effects of propolis on cariogenic bacteria. Several studies have demonstrated an in vitro inhibition of Streptococcus mutans group growth by propolis from diff erent geographical origins $[40,41]$.

We demonstrated the antibacterial effectiveness of propolis in the oral mucosa disease including oral candidiasis. In this study, the control and PBS groups did not show any difference in the number of bacteria at observation periods. However, the antibacterial activity of $3 \% \mathrm{NaOCl}$ and $0.1 \% \mathrm{CHX}$ was similar as the same time. A significant reduction in the cultivable numbers of bacteria was achieved with the use of 3\% $\mathrm{NaOCl}, \quad 0.1 \% \mathrm{CHX}$ and $10 \mu \mathrm{l} / \mathrm{ml}$ propolis. The remarkable antibacterial activities had greater than the inhibition zones diameter of $3 \% \mathrm{NaOCl}$ and $0.1 \% \mathrm{CHX}$. The propolis used showed good capacity of diffusion in agar. It succeeded in inhibiting the growth of the microorganisms. It seems that the antimicrobial activity of propolis occurs in a dose-dependent manner. According to the findings of the study presented here, it is concluded that the $10 \mathrm{\mu l} / \mathrm{ml}$ propolis was superior to CHX in terms of bacterial elimination against $C$. albicans strain.

The development of new agents for the treatment of the oral diseases is of great relevance. Furthermore, the microorganisms studied in this work are of great relevance in dentistry and are involved with oral mucosa lesions. The propolis is expected to bring its therapeutic activity to the patient with greater comfort in order to benefit oral health.

Propolis agent for the present study showed a significant role related to oral diseases, further study is also required to identify the effect of propolis with the different Streptococcus mutans. Dodwad et al showed that the study was to investigate the effectiveness of a propolis-containing mouthrinse in inhibition of plaque formation and improvement of gingival health. This present study suggested that propolis might be used as a natural mouthwash. Therefore, our findings could recommend to be used as a propolis gargle products as an alternative to chemical mouthwashes[42]. Therefore, the antimicrobial action observed in this new formulation suggests its use as an alternative adjuvant therapy for infectious conditions of the oral cavity, without causing major local or systemic adverse effects. It will be able to be efficient against oral infections by $C$. albicans. A step further should be given to evaluate the cytotoxicity of this propolis.

\section{Conclusion}

Propolis can be useful as an antimicrobial agent in traditional medicine worldwide and in the development of oral hygiene products for the prevention of the oral mucosa disease including oral candidiasis.

\section{References}

[1] D. Nicodemo, J. D. De, R. H. Couto, E. Malheiros, Heney bee lines selected for high propolis production also have superior hygienic behaviors and increased honey and pollen stores. Genetics and Molecular Research, Vol.12, NO.4, pp.6931-6938, 2013.

DOI: http://dx.doi.org/10.4238/2013.December.19.12

[2] W. M. Thomso, Propolis, The Medical journal of Australia. Vol.153, No.11-12, pp.654, 1990.

[3] F. Borrelli, P. Maffia, L. Pinto, A. Ianaro, A. Russo, F. Capasso et al, Phytochemical compounds involved in the anti-inflamatory effect of propolis extract. Fitoterapia, Vol.73, No.1, pp.53-63, 2002.

DOI: http://dx.doi.org/10.1016/S0367-326X(02)00191-0

[4] A. Kujungiev, I. Tsvetkova, Y. Serkedjieva, V. Bankova, R. Christov, S. Popov, Antibacterial, antifungal and antiviral activity of propolis of different geographic origin. Journal of Ethnopharmacology, Vol.64, No.3, pp.235-240, 1999. DOI: http://dx.doi.org/10.1016/S0378-8741(98)00131-7

[5] N. Orsolic, I. Basic, Immunomodulation by water-soluble 
derivative of propolis: a factor of antitumor reactivity. Journal of Ethnopharmacolo

gy, Vol.84, No.2-3, pp. 265-273, 2003.

DOI: http://dx.doi.org/10.1016/S0378-8741(02)00329-X

[6] D. Skaba, T. Morawiec, M. Tanasiewicz, et al, Influence of the toothpaste with brazilian ethanol extract propolis on the oral cavity health. Evidence-Based Complementary and Alternative Medicine, Vol.2013, No.2013, pp.1155-1567, 2013.

[7] T. Tatefuji, N. Izumi, T. Ohta, S. Arai, M. Ikeda, Kurimot, Isolation and identification of compounds from Brazilian propolis which enhance macrophage spreading and mobility. Biological \& Pharmaceutical Bulletin, Vol.19, No.7, pp.966-970, 1996.

DOI: http://dx.doi.org/10.1248/bpb.19.966

[8] A. L. Hamedt, I. C. Ortiz, P. A. García-Huertas, J. Sáenz , A. C. Araujo, J. C. Mattos, M. A. Rodríguez-Gazquez, O. Triana-Cháve, Cytotoxic, mutagenic and genotoxic evaluation of crude extracts and fractions from Piper jericoense with trypanocidal action. Acta Tropica, Vol.19, No.131, pp.92-97, 2013.

[9] W. Więckiewicz, M. Miernik, M. Więckiewicz, T. Morawiec, Does propolis help to maintain oral health? Evid Based Complement Alternat Med, 35, pp.1062, 2013.

[10] A. H. Acikelli, S. Gustmann, W. Bardenheuer, J. Klein, U. Dembinski, B. Kohl, K. T. Yip, A. Nazif, R. Stoll, D. Strumberg, D. Díaz-Carballo, Flavonoids isolated from Caribbean propolis show cytotoxic activity in human cancer cell lines. Int J Clin Pharmacol Ther, Vol.51, No.1, pp.51-53, 2013.

DOI: http://dx.doi.org/10.5414/CPP51051

[11] M. M. Viuda, N. Y. Ruiz, L. J. Fern L. J. Perez, Functional properties of honey. propolis, and royal jelly, J Food Sci, Vol.73, pp.117 - 124, 2008.

DOI: http://dx.doi.org/10.1111/j.1750-3841.2008.00966.x

[12] Noh SB, Evaluation of the anti-bacterial effect and cytotoxicity on Korean propolis, Chosun University, Korea, 2008.

[13] J. B. Daleprane, D. S. Abdalla, Emerging roles of propolis: antioxidant, cardioprotective, and antiangiogenic actions. Evid Based Complement Alternat Med : Epub, pp.175-135, 2013.

[14] A. K. Kuropatnicki, E. Szliszka, M. Kłósek, W. Król, The beginnings of modern research on propolis in poland. Evid Based Complement Alternat Med: Epub, Vol.983, pp.974, 2013.

[15] C. O. Frozza, C. S. Garcia, G. Gambato, M. D. de Souza, et al, Chemical characterization, antioxidant and cytotoxic activities of Brazilian red propolis. Food Chem Toxicol, Vol.52, pp.137-142. 2013.

DOI: http://dx.doi.org/10.1016/j.fct.2012.11.013

[16] M. C. Marcucci, Propolis: chemical composition, biological properties and therapeutic activity. Apidologie, Vol.26, pp.83-99, 1995.

DOI: http://dx.doi.org/10.1051/apido:19950202

[17] Y. K. Park, M. H. Koo, J. A. S. Abreu, M. Ikegaki, J. A. Cury, P. L. Rosalen, Antimicrobial activity of propolis on oral microorganisms. Curr Microbiol, Vol.36, pp.24-28, 1998.

DOI: http://dx.doi.org/10.1007/s002849900274

[18] D. O. Kim, O. K. Y. Chun, Y. L. Kim, H. Y. Moon, C. Y. Lee, Quantification of polyphenolics and their antioxidant capacity in fresh, plums. J Agri. Food Chem, Vol.51. pp.6509 - 6515, 2003.

DOI: http://dx.doi.org/10.1021/jf0343074

[19] I. Kubo, Muroi H, Himejima M. Antimicrobial activity of Green tea flavor components and their combination effects. J Agri Food Chem, Vol. 40, pp. 245-248, 1992. DOI: http://dx.doi.org/10.1021/jf00014a015

[20] Maryam ZJ, Hasan T, Majid R, Propolis: A New Alternative for Root Canal Disinfection. Vol.7, No.3, pp.127-133, 2012.

[21 ]M. Schifter, S. C. Yeoh, H. Coleman, A. Georgio, Oral mucosal diseases: the inflammatory dermatoses, Aust Dent J, Vol.55, No.1, pp.23-38, 2010.

DOI: http://dx.doi.org/10.1111/j.1834-7819.2010.01196.x

[22] A. Akpan, R. Morgan, Oral candidiasis. Postgrad Med J, Vol.78, pp.445-455, 2002.

DOI: http://dx.doi.org/10.1136/pmj.78.922.455

[23] P. A. Castro, V. L. Bom, N. A. Brown, R. S. Almeida, L. N. Ramalho, M. Savoldi, M. H. Goldman, A. A. Berretta, G. H. Goldman, Identification of the cell targets important for propolis-induced cell death in Candida albicans. Fungal Genet Biol, Vol.60, pp.74-86, 2013. DOI: http://dx.doi.org/10.1016/j.fgb.2013.07.001

[24] L. P. Kantheti, B. Reddy, S. Ravikumar, C. H. Anuradha, P. Chandrasekhar, M. R. Rajeswari, Isolation, identification, and carriage of candidal species in PHLAs and their correlation with immunological status in cases with and without HAART. J Oral Maxillofac Pathol, Vol.16, No.1, pp.38 - 44, 2012.

DOI: http://dx.doi.org/10.4103/0973-029X.92971

[25] B. V. Ready, G. R. Sridhar, C. H. Anuradha, Chandrasekhar p, Lingamaneni KP, Malingnant melanoma of the mandibular gingive : rare occurrence. Indian J Dent Res, Vol.21, No.2, pp. 302-305, 2010. 
DOI: http://dx.doi.org/10.4103/0970-9290.66644

[26] M. V. Martin, The use of fluconazole and itraconazole in the treatment of Candida albicans infections: a review. Journal of Antimicrobial Chemotherapy, Vol.44, No.4, pp. 429-437, 1999.

DOI: http://dx.doi.org/10.1093/jac/44.4.429

[27] J. Cuttner, K. M. Troy, L. Funaro, R. Brenden, E. J. Bottone, Clotrimazole treatment for prevention of oralcandidia is in patients with acute leukemia undergoing chemotherapy, Results of a double-blind study. Am J Med, Vol.81, No.5, pp.771-774, 1986.

DOI: http://dx.doi.org/10.1016/0002-9343(86)90342-6

[28] A. Byström, G. Sundqvist, Bacteriologic evaluation of the effect of 0.5 percent sodium hypochlorite in endodontic therapy. Oral Surg Oral Med Oral Pathol, Vol.55, No.3, pp.307 - 312, 1983.

DOI: http://dx.doi.org/10.1016/0030-4220(83)90333-X

[29] L. Grossman, B. Meiman, Solution of pulp tissue by chemical agents. J Am Dent Assoc, Vol.8, pp. 223 - 225, 1982.

[30] E. Pashley, N. Birdsong, K. Bowman, D. Pashley, Cytotoxic effects of $\mathrm{NaOCl}$ on vital tissue. J Endod, Vol.11, No.12, pp.525 - 528, 1985.

DOI: http://dx.doi.org/10.1016/S0099-2399(85)80197-7

[31] O. Fardak, R. Turnbull, A review of literature on use of chlorhexidine in dentistry. J Am Dent Assoc, Vol.112, No.16, pp.863 - 869, 1985.

[32] G. Greenstein, C. Berman, J. R. Chlorhexidine, An adjunct to periodontal therapy. J Periodontol, Vol.57, No.6, pp.370 $-376,1986$.

DOI: http://dx.doi.org/10.1902/jop.1986.57.6.370

[33] M. Jeansonne, R. White, A comparison of 2.0\% chlorhexidine gluconate and 5.25\% sodium hypochlorite as antimicrobial endodontic irrigants. J Endod, Vol.20, No.6, pp.276 - 278, 1994.

DOI: http://dx.doi.org/10.1016/S0099-2399(06)80815-0

[34] C. B. Walker, The acquisition of antibiotic resistance in the periodontal microflora. Periodontol 2000, Vol.10, pp.79-88, 1996.

DOI: $\underline{\text { http://dx.doi.org/10.1111/j.1600-0757.1996.tb00069.x }}$

[35] T.A. Kost, Expression vectors and delivery systems tools for determining gene function and gene therapy. Curr Opin Biotechnol, Vol.10, No.5, pp.409-10, 1999. DOI: http://dx.doi.org/10.1016/S0958-1669(99)00001-4

[36] R. H. Selwitz, A. Ismail, N. B. Pitts, Dental caries. Lancet, Vol.369, pp.51-59, 2007.

DOI: http://dx.doi.org/10.1016/S0140-6736(07)60031-2

[37] C. B. Walker, The acquisition of antibiotic resistance in the periodontal microflora. Periodontology 2000, Vol.10, pp.79-88, 1996.

DOI: http://dx.doi.org/10.1111/j.1600-0757.1996.tb00069.x

[38] E. L. Ghisalberti, Propolis: a review, Bee World. Vol.60, No.2, pp.59-84, 1960.

[39] Y. K. Park, M. H. Koo, J. A. Abre, M. Ikegaki, J. A. Cury, P. L. Rosalen, Antimicrobial activity of propolis on oral microorganisms. Current Microbiology, Vol.36, No.1, pp.2428, 1998.

DOI: http://dx.doi.org/10.1007/s002849900274

[40] G. A. Burdock, Review of the Biological properties and toxicity of bee propolis(propolis). Food Chem Toxicol, Vol.36, No.4, pp. 347-363, 1998.

DOI: http://dx.doi.org/10.1016/S0278-6915(97)00145-2

[41] S. A. Duailibe, A. G. Gonçalves, F. J. Ahid, Effect of a propolis extract on Streptococcus mutans counts in vivo. J Appl Oral Sci, Vol.15, No.5, pp.420-423 2007.

DOI: http://dx.doi.org/10.1590/S1678-77572007000500009

[42] V. Dodward, B. J. Kukreja, Propolis mouthwash: A new beginning.y J Indian Soc Periodontol. Vol.15, No.2, pp.121-155, 2011.

\section{Hyeon-Sook Kwun}

[Regular member]

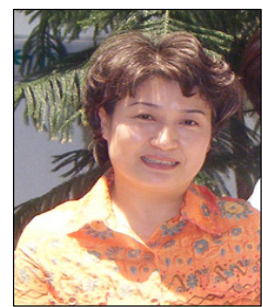

- Feb. 1996 : Kyungnam Univ., The Department of Education, MS

- Feb. 1999 : Kyungnam Univ., The Department of Education, $\mathrm{PhD}$

- Mar. 1984 Current : Masan Univ., Dental Hygiene, Professor

$<$ Research Interests $>$

Public Oral Health 
Seoul-Hee Nam

[Regular member]

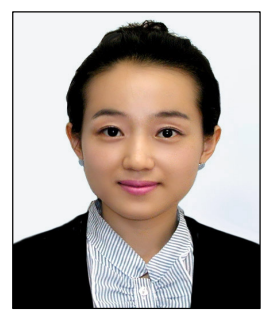

$<$ Research Interests $>$

Oral Anatomy, Cell Biology

Min-Kyoung Park

[Regular member]

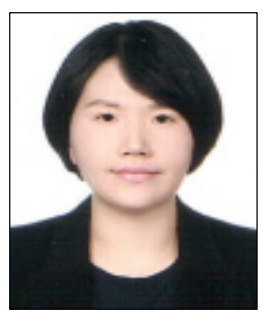

- Feb. 2009 : Kyungnam Univ., The Department of Education, MS

- Feb. 2011 : Kyungpook National Univ.,complete $\mathrm{PhD}$

- Mar. 2012 Current

Kyungwoon Univ., Professor

$<$ Research Interests $>$

Oral Biology
Hee-Sae Cheon

[Regular member]

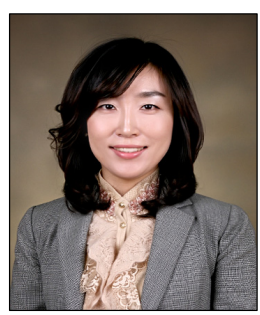

- Feb. 2012 : Daegu Haany Univ., The Department of Public Health, MS

- Feb. 2014 : Daegu Haany Univ., The Department of Public Health, Complete $\mathrm{PhD}$

- Sep. $2009 \sim$ Current : Adjunct professor

$<$ Research Interests $>$

Public Oral Health, Dental Hygiene
Mi SooK Cho

[Regular member]

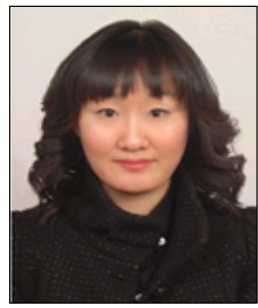

- Feb. 2013 : Kosin Univ., School of Medical, $\mathrm{PhD}$

- Mar. 2012 Current : Coonhae Coll., Professor

$<$ Research Interests $>$

Oral Health Education, Public Oral Health 